
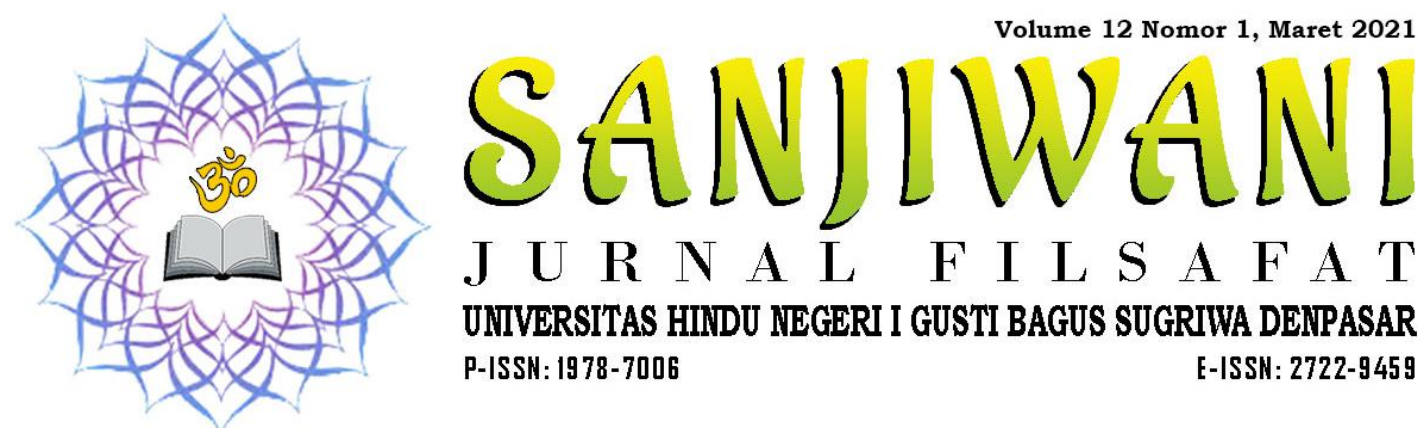
UNIVERSITAS HINDU NEGERI I GUSTI BAGUS SUGRIWA DENPASAR P-ISSN: 1978-7006

E-ISSN: 2722-9459

\title{
Empirisme Penggunaan Tumbuhan pada Pengobatan Tradisional Bali: Lontar Taru Pramana dalam Konstruksi Filsafat Ilmu
}

\author{
Putu Eka Sura Adnyana \\ DPP Peradah Indonesia Bali \\ ekasuraadnyana@gmail.com
}

\begin{tabular}{|ll|}
\hline Keywords: & ABSTRACT \\
\hline Lontar Taru & Man is never separated from the desires in the fulfillment \\
Pramana; & ofhis life. The development of life also affects the form of human \\
Traditional & desire. The influence of materialism is sometimes human \\
Medicine; & hedonism which is sometimes incompatible with Hindu ethics. \\
Construction of the & But Epicurean Hedonism has a different view to hedonism in \\
Philosophy of & general. This paper aims to describe Epikuros's thoughts \\
Science & related to Hedonism. The pleasure-oriented attitude of \\
& hedonism is different from Epikuros hedonism that not only \\
& seeks material pleasure but also seeks spiritual pleasure. \\
& Spiritual pleasure can make man calm and wise, such \\
& situations are commonly called anarakxia. The hedonism \\
& taught by Epikuros aligns with the teachings on Hindu ethics \\
& that not only pursue earthly pleasures but are led to try to \\
control themselves from earthly pleasures in order to achieve & the happiness of life. The benefits of this paper can contribute \\
to the understanding of the intersection between Epicurean & \\
thought and Hindu ethical views.
\end{tabular}

\begin{tabular}{|ll|}
\hline Kata Kunci & ABSTRAK \\
\hline Lontar Taru & Taru Pramana merupakan sebagai lontar yang \\
Pramana; & mengiventarisasi nama-nama tumbuhan berdasarkan \\
Pengobatan & fakta realita dilapangan yang diketahui oleh pangawi \\
Tradisional; & "pengarang" teks tersebut. Ada 168 nama tumbuhan Bali \\
Kontruksi Filsafat & yang ada dalam Usada Taru Pramana. Pengetahuan- \\
Ilmu & pengetahuan tersebut tersusun secara sistematis oleh \\
& pangawi dalam teks tersebut merupakan ilmu \\
& pengetahuan dalam penggunaan tumbuh-tumbuhan \\
& dalam pengobatan tradisional Bali. dalam filsafat, \\
& pengetahuan tersebut dikenal dengan istilah empirisme. \\
\hline
\end{tabular}

64 | SANJIWANI: Jurnal Filsafat Vol. 12 No. 1, Maret 2021 
Lontar Taru Pramana merupakan naskah kuno yang ditulis dalam lontar dengan menggunakan aksara Bali. Isinya menceritakan jenis tumbuh-tumbuhan yang dapat dijadikan obat-obatan. Taru Pramana juga disebut sebagai usadha karena memuat pengetahuan tentang obatobatan atau ramuan obat serta mengobati dengan memakai ramuan dari bahan tumbuh-tumbuhan yang diracik secara tradisional. Tentunya itu menandakan bahwa pengalaman para leluhur terdahulu dalam mengobati penyakit telah memahami ekosistem tumbuhtumbuhan, yang berguna dalam proses penyembuhan dan pengobatan. Sangat jelas diuraikan penggunaan tumbuh-tumbuhan yang dapat digunakan sebagai obat pada lontar Taru Pramana, dengan disangga oleh tiga hal mendasar dalam filsafat yaitu ontologis, epistemologi dan aksiologinya. Ketiga hal tersebut berkaitan dalam membangun ilmu pengobatan herbal tradisional dengan menggunakan tumbuh-tumbuhan sebagai fokus utamanya.

\section{PENDAHULUAN}

Konsep Tri Hita Karana jika merujuk pada warisan manuscript masyarakat Bali. Salah satunya adalah lontar Taru Pramana. Lontar Taru Pramana adalah lontar yang berisi tentang khaziat tumbuhan dalam pengobatan tradisional Bali. dalam teks lontar tersebut sangat jelas, tersusun secara sistematis pengetahuan berkaitan dengan penggunaan tumbuh-tumbuhan sebagai bahan obat dalam pengobatan tradisional Bali, selain itu lontar Taru Pramana merupakan lontar yang mengiventarisasi nama-nama tumbuhan berdasarkan fakta realita dilapangan yang diketahui oleh pangawi "pengarang" teks tersebut. Ada 168 nama tumbuhan Bali yang ada dalam Usada Taru Pramana (Jumadiah, 2009 : ii). Pengetahuan-pengetahuan tersebut tersusun secara sistematis oleh pangawi dalam teks tersebut merupakan ilmu pengetahuan dalam penggunaan tumbuhtumbuhan dalam pengobatan tradisional Bali. dalam filsafat, pengetahuan tersebut dikenal dengan istilah empirisme.

Empirisme adalah aliran dalam filsafat yang menyatakan bahwa semua pengetahuan berasal dari pengalaman manusia. Empirisme menolak anggapan bahwa manusia telah membawa fitrah pengetahuan dalam dirinya ketika dilahirkan. Catatan-catatan dalam lontar usada terutamanya lontar taru pramana wajib dipahami, sebagai bentuk empirisme pengetahuan yang berasal dari pengalaman manusia "pengarang" dalam menuliskan isi teks tersebut. Teks tersebut adalah informasi berkaitan dengan tumbuh-tumbuhan dalam pengobatan tradisional maka wajib diberikan pendekatan pengobatan masa kini, dengan mengintegrasikan budaya kedalam ranah pengobatan dan kesehatan (Utami, 2019). Melalui isi teks lontar Taru Pramana harus wajib diberikan perhatian khusus dengan mengkontruksikan pemahaman filsafat ilmu kedalamnya. Oleh karena filsafat ilmu berusaha menjelaskan masalah-masalah 
dimulai dari suatu konsep dan pernyataan, sehingga dapat dinyatakan sebagai ilmiah. Sebagaimana teks lontar Taru Pramana memuat konsep-konsep pengetahuan penggunaan tumbuhan-tumbuhan dalam pengobatan tradisional agar dapat dinyatakan ilmiah, maka harus dikontruksikan dengan pemikiran filsafat ilmu, baik secara ontologis, epistemologis, dan aksiologis keilmuan lontar Taru Pramana.

Keragaman jenis tumbuhan obat dan pemanfaatan tumbuhan dalam lontar Taru Pramana sangat penting dilakukan, sebagaimana usulan Universitas Hindu Negeri I Gusti Bagus Sugriwa akan membuka prodi kesehatan komplementer, tentunya dengan membuka prodi kesehatan komplementer tersebut harus mampu mentransformasikan pengetahuan-pengetahuan dalam teks lontar usadha, agar dapat dinyatakan keilmiahannya dan mampu menghasilkan produk-produk baru kesehatan berbasis kearifan lokal Bali. Disisi lain juga, ikut berperan mendukung progam pemerintah Bali yaitu implementasi pola pembangunan semesta berencana Bali yang dicanangkan oleh Gubernur Bali 2018-2023 melalui visi nangun sat kerthi loka Bali yakni pembangunan alam Bali, pembangunan krama atau manusia Bali, dan pembangunan budaya Bali.

Taru Pramana merupakan bagian dari budaya Bali yakni pengetahuan tentang pengobatan tradisional. Hal ini diharapkan menjadi salah satu rujukan dalam pengobatan tradisional Bali, pengobatan tradisional Bali komplementer, maupun pengobatan tradisional Bali intergratif (Arsana, 2019). Tulisan ini mencoba untuk memahami keragaman jenis penggunaan tumbuh-tumbuhan pada pengobatan tradisional Bali dalam kontruksi filsafat ilmu. Tentunya bertujuan untuk menjelaskan jenis tumbuhan obat yang tercatat dalam lontar usada Taru Pramana dan pemanfaatannya dalam pengobatan tradisional Bali, serta diharapkan mampu memberikan sumbangsih untuk kemajuan ilmu pengetahuan dengan kebermanfaatannya kepada masyarakat luas.

\section{PEMBAHASAN}

\subsection{Lontar Taru Pramana}

Lontar Taru Pramana merupakan naskah kuno yang ditulis dalam lontar dengan menggunakan aksara Bali. Isinya menceritakan jenis tumbuh-tumbuhan yang dapat dijadikan obat-obatan. Taru Pramana juga disebut sebagai usadha karena memuat pengetahuan tentang obat-obatab atau ramuan obat serta mengobati dengan memakai ramuan dari bahan tumbuh-tumbuhan yang diracik secara tradisional (Jumadiah, 2009 : ii). Secara etimologi kata Taru memiliki arti pohon, tumbuhan dan pramana berarti tenaga. Jadi Taru Pramana adalah pohon atau tumbuhan yang memiliki khasiat untuk obat-obatan. Selanjutnya gambaran teks lontar Taru Pramana, dijelaskan sebagai berikut.

\subsubsection{Deksripsi Naskah Lontar Taru Pramana}

Lontar Taru Pramana merupakan lontar yang memuat banyak jenis tumbuh-tumbuhan yang dapat dimanfaatkan kegunaannya dalam pengobatan tradisional. Sukersa (1996) telah melakukan penelitian terhadap lontar Taru Pramana dalam analisis filologis. Penelitian tersebut dengan Teks Taru Pramana versi Mpu Kuturan koleksi Pusat Kajian Lontar Universitas Udayana ikut dijadikan data primer bersama 3 naskah Usada

66 | SANJIWANI: Jurnal Filsafat Vol. 12 No. 1, Maret 2021 
Taru Pramana lainnya yang seversi yang ditemukan di masyarakat maupun di lembaga-lembaga penyimpanan naskah. Tulisan ini mengacu pada data penelitian filologis lontar Taru Pramana (Sukersa, 1996). Adapun deskripsi spesifikasi lontar Taru Pramana, dikutip pada tulisan Sukersa (2017:2-3) sebagai berikut.

1. Judul naskah : Lontar Taru Pramana.

2. Identitas nomor : Nomor urut 593; kode kropak 339, nomor naskah (Rt)-.

3. Ukuran naskah : 3,5 x 42,5cm / 3x33cm.

4. Keadaan naskah : Cukup baik dan utuh.

5. Tulisan naskah : Aksara Bali

6. Bahasa : Bahasa Jawa Kuno dan Bahasa Bali.

7. Tebal naskah : 26 lembar.

8. Bentuk teks : Prosa.

9. Umur naskah : Tertulis dalam kolofon tahun 1898 Saka.

10. Bahan naskah : Daun Lontar

11. Kolofon naskah : Pada bagian catatan penutup tertulis puput sinurat ring dina, A, U, Wara Landep, tang, ping 10, sasih, ka, 5, rah, 8, teng, 9, Isaka warsa yusaning loka, 1898. Ksamakena wirupaning aksara, bap kawenang. Kasurat antuk I Gusti Agung Putu Gede Dendi, ring Jero Kaleran, Desa Padang Sambean, Kecamatan Denpasar, Bumi Badung. Lontar drewen Fakultas Sastra Udayana ring Denpasar, Bumi Badung. Om shanti, shanti, shanti. Om. 'Selesai ditulis pada hari Selasa, Umanis, Landep, hari kesepuluh paro bulan terang, bulan kelima, angka satuannya 8, angka puluhannya 9, tahun Saka 1898. Maafkan kejelekan tulisannya, banyak yang tidak diketahui. Ditulis oleh I Gusti Agung Putu Gede Dendi, dari Jero Kaleran, Desa Padang Sambean, Kecamatan Denpasar, Kabupaten Badung. Lontar milik Fakultas Sastra Udayana di Denpasar, Kabupaten Badung. Ya Tuhan Semoga senantiasa damai selamanya.

\subsubsection{Isi Lontar Taru Pramana}

Ringkasan isi teks lontar Taru Pramana diawali dengan mengisahkan seorang tabib bernama Mpu Kuturan yang sangat terkenal dengan keberhasilannya menyembuhkan pasien-pasiennya. Namun berjalannya waktu tiba-tiba datang masa suramnya, setiap orang yang diobati tidak kunjung sembuh dan bahkan banyak yang meninggal. Pikirannya menjadi gusar dan itulah sebabnya beliau pasrah dan bertekad "jengah" untuk kesembuhan pasiennya maka beliau melakukan tapa semadi di kuburan. Setelah genap satu bulan tujuh hari (Salek sapta dina) bersemedi di atas tempat pembakaran mayat, turunlah Bhatari Durga dari kayangan dan berkenan memberikan anugerah. Mpu Kuturan menjadi memiliki kemampuan dan pengetahuan untuk berkomunikasi memanggil dan menanyai pepohonan (taru), tumbuhan melata (lata), rerumputan (trna), semak-semak (gulma) tentang khasiatnya masing-masing yang dapat dijadikan bahan obat-obatan. 
Pertama-tama datanglah pohon beringin menghadap, disusul oleh silaguri, dedap, kelor, pohon maja, kepundung, dan tetumbuhan lainnya. Dialog Mpu Kuturan dengan tumbuh-tumbuhan terus berlanjut. Para pohon datang bergantian menyebutkan nama, kandungan zat, bagianbagian yang dapat dimanfaatkan, dan kegunaanya untuk mengobati suatu jenis penyakit. Bermacam- macam bagian dari pohon, baik berupa umbi, akar, batang, kulit, daun, buah, dan sebagainya disebutkan memiliki sifat kandungan tersendiri. Ada yang bersifat panas, hangat, dumalada (sedangsedang), dingin, maupun tis (sejuk). Dari bagian-bagian pohon itu dapat dijadikan obat luar maupun obat dalam yang berupa boreh atau param, urap, kompres, sembur, jamu, tetes (tutuh), dan sebagainya. (Sukersa, 1996, 2017; Jumadiah, 2009).

Semua hasil komunikasi Mpu Kuturan dengan tumbuh-tumbuhan tersebut dicatat kembali oleh putra beliau yang bernama Prabu Narayasa. Cerita tersebut ditutup dengan kalimat "inggih puput, pascat sampun sang Prabhu Mpu Kuturan, Ida ngarad taru sahananing sane dados anggen tamba. Mungguing atur taru-taru punika, sami kasuratang olih Ida Sang Prabhu Narayasa, taler kulina jana kukuhing samahita, kaprenah, putra antuk Ida Sang Prabhu Mpu Kuturan". Usada Taru Pramana ini dapat pula dikatakan sebagai Sastra Usada karena ada tokoh pelaku dan memiliki unsur naratif (Sukersa, 2017 : 6), sehingga menarik bagi pembaca dan diarahkan dengan gambaran imajinasi yang dikombinasikan dengan pengetahuan factual terhadap penggunaan tumbuh-tumbuhan tersebut sebagai obat dalam pengobatan tradisional. Antropolog Foster dan Anderson menemukan bahwa dalam masyarakat tradisional penyebab penyakit dapat dibagi atas 2 kelompok yakni sakit yang disebabkan oleh kausa naturalistik dan kausa personalistik. Pada konsep naturalistik diakui adanya keseimbangan di dalam tubuh manusia. Jika keseimbangan itu terganggu oleh pengaruh faktor luar, misalnya pengaruh lingkungan alam: cuaca, debu, zat kimia, sosial, dan pengaruh dalam faktor fisik seperti umur, emosi dan lain-lain maka sakitlah mereka. Faktor kausa personalistik ini berbentuk non manusia dan gaib seperti roh halus, setan, hantu, dan sebagainya. Bagi masyarakat Bali konsep dari Foster dan Anderson itu antara kausa sekala dengan kausa naturalistik disamakan, serta kausa niskala disamakan dengan kausa personalistik (Nala dalam Sukersa, 2017 : 13).

Fungsi Usada Taru Pramana lainnya yang tidak kalah pentingnya adalah inventarisasi ratusan nama-nama tumbuhan khas Bali. Back to nature "kembali kepada alam" demikian slogan-slogan dunia untuk menjaga alam dan ekosistemnya. Begitupula dengan isi teks lontar Taru Pramana bisa menggugah para akademisi kesehatan, praktisi, budayawan bahkan pemerintah untuk melestarikan, menanam kembali, dan menginventarisasi jenis tumbuh-tumbuhan sebagai bentuk kebudayaan Bali dalam seni pengobatan tradisional. Agar keberlangsungan ekosistem dapat terjaga dengan mentransformasikannya dalam perubahan jaman dan tetap mengedepankan nilai-nilai kearifan lokal Bali. 


\subsection{Empirisme Penggunaan Tumbuh-Tumbuhan dalam Lontar Taru Pramana}

Empirisme merupakan aliran filsafat yang menyatakan bahwa semua pengetahuan berasal dari pengalaman manusia. Empirisme menolak anggapan bahwa manusia telah membawa fitrah pengetahuan dalam dirinya ketika dilahirkan. Empirisme secara etimologis berasal dari kata bahasa Inggris empiricism dan experience. Kata-kata ini berakar dari kata bahasa Yunani (empeiria) dan dari kata experieti yang berarti "berpengalaman dalam", "berkenalan dengan", "terampil untuk". Empirisme adalah aliran dalam filsafat yang berpandangan bahwa pengetahuan secara keseluruhan atau parsial didasarkan kepada pengalaman yang menggunakan indera. dalam tulisan ini empirisme yang dimaksud adalah semua pengetahuan penggunaan tumbuhtumbuhan pada pengobatan tradisional yang termuat dalam lontar Taru Pramana. Semua pengetahuan tersebut merupakan wujud konkrit dari pengalaman manusia yang dituangkan dan terdokumentasikan dalam khazanah teks lontar terutamanya usadha. Tentunya itu menandakan bahwa pengalaman para leluhur terdahulu dalam mengobati penyakit telah memahami ekosistem alam yang berguna dalam proses penyembuhan penyakit tersebut. Hal itu sangat jelas diuraikan penggunaan tumbuh-tumbuhan yang dapat digunakan sebagai obat pada lontar Taru Pramana. Adapun sebagai berikut:

1. Taru Bingin atau pohon beringin (nama ilmiah: ficus benjamina) digunakan akar, daun, kayunya untuk mengobati rasa sakit menusuk-nusuk pada perut bagian samping;

2. Kaselaguwi atau sidaguri/ seleguri (nama ilmiah: sidarhombhifolia I) digunakan serat kayu untu jamu dan urap bayi umur 5 (lima hari);

3. Taru Dadap atau pohon dadap (nama ilmiah: erythrina sumbumbrans) digunakan kayu dan daun untuk obat perut kembung;

4. Taru Kelor atau pohon kelor (nama ilmiah: moringa oleifera juss) digunakan daun untuk pengobatan sakit mata;

5. Taru Bila atau Pohon Bila (nama ilmiah: aegle marmelos) digunakan serat kayu untuk param obat sakit biri-biri;

6. Taru Kalenco atau Pohon Kalence (nama ilmiah: diospyros malabarica) bisa digunakan semua aspek pada tumbuhan untuk obat batis beteg "bengkak";

7. Taru Kepuh atau Kelumpang tidak bisa dijadikan obat;

8. Taru Kepah atau Pohon Kepah (Stercukea foetida L) digunakan semua bentuknya untuk obat lumpuh;

9. Taru Beilmiahg Gada atau kaktus (nama ilmiah: cereus peruviabus) digunakan getahnya untuk obat lepra;

10. Taru Pakel atau pohon pakel (nama ilmiah: mangifer sp) dapat digunakan semuanya untuk jamu nuba beling (abortus);

11. Taru Sumaga atau pohon jeruk (nama ilmiah: citrus nolibis) dapat digunakan semua tumbuhannya untuk sakit tuju atau sakit encok;

12. Taru Kepundung atau kepundung (nama ilmiah: baccauread dulcis) dapat digunakan getahnya untuk mengobati bengkak pada pipi;

69 | SANJIWANI: Jurnal Filsafat Vol. 12 No. 1, Maret 2021 
13. Poh Weni atau pohon weni (nama ilmiah: magifera $s p$ ), semua bentuknya dapat digunakan untuk obat membersihkan perut (urus-urus) dan sembur untuk obat lemah jantung;

14. Taru Cenangga atau Pohon Mangga (nama ilmiah: milingtonia hortensis) daunnya dapat digunakan untuk jamu mengobati panas;

15. Taru Suren atau Pohon Suren (nama ilmiah: toona sureni merr) digunakan serat kayu, daun, dan akar untuk mengobati bengkak dan koreng;

16. Taru Sentul atau Pohon Kecapi (nama ilmiah: sandoricum koetjape merr) digunakan daun, akar, untuk mengobati diare dan menghilangkan panas pada perut;

17. Taru Sotong atau pohon jambu biji (nama ilmiah: psidium guajava L) digunakan daunnya untuk menghentikan diare;

18. Taru Gatep atau pohon gayam (nama ilmiah: inocarpus fagiferus) digunakan serat kayunya untuk loloh menghilangkan sakit desentri;

19. Taru Pule atau pohon pule (nama ilmiah alxian reinwardtii) digunakan daunnya untuk jamu berkhaziat mengobati panas;

20. Taru Cemara atau Pohon Cemara (nama ilmiah: casuria equisetifolia) digunakan daunnya untuk mengobati sakit mata dan mengobati orang sakit akibat guna-guna "jaran guying;

21. Taru Kliki atau pohon jarak kepyar (nama ilmiah: Jayatropha curcus L) digunakan daunnya untuk mengobati jari-jari bengkak bernanah (katimubulan) dan obat anyang-anyangan "gangguan pada saluran kencing";

22. Taru Nangka atau pohon nangka (nama ilmiah: Annona murricata L) digunakan daun, getah untuk mengobati perut kembung tidak bisa buang air besar (berak) dan obat mual-mual;

23. Taru Awar-awar atau pohon awar-awar (nama ilmiah: ficus septica) digunakan daun dan akar untuk mengobati jamu obat mutaber dan obat digigit ular belang (lipi poleng);

24. Taru Wit Jeruju atau pohon daruju (nama ilmiah: acanthus ebracatus) digunakan akarnya untuk mengobat rematik;

25. Taru Pulet atau pohon pulet digunakan daun dan bunganya untuk mengobati batuk;

26. Taru Belimbing atau pohon belimbing (nama ilmiah: averrhoa) digunakan buah untuk mengobati batuk, urap untuk hamil, dan sakit asma;

27. Taru Delima atau pohon delima (nama ilmiah: Punia granatum L) digunakan semua pohonnya untuk obat sakit perut;

28. Taru Tangi atau pohon bangur (nama ilmiah: lagerstroemiaspeciosa) digunakan kulit kayunya digunakan untuk obat sulit tidur;

29. Taru Kapopoh atau pohon kepopoh digunakan daun, getah dan kulit kayunya untuk mengobati urap perut orang hamil;

30. Taru Buyung-buyung atau pohon buyung-buyung (nama ilmiah: vernonia cineria less) digunakan daunnya untuk mengobati sakit ayan atau epilepsy;

31. Tabya Dakep atau cabe puyang (nama ilmiah: piper retrpfractum) digunakan serat kulit, daun dan akarnya untuk mengobati obat sakit ayan;

32. Taru kepel atau pohon kepel (nama ilmiah: manglietia glauca) digunakan serat kulitnya untuk mengobati dan memperlancar proses melahirkan;

70 | SANJIWANI: Jurnal Filsafat Vol. 12 No. 1, Maret 2021 
33. Taru belimbing manis atau blimbing manis (nama ilmiah: averrhooa bilimbi) digunakan daunnya untuk mengobati orang hamil;

34. Belimbing besi atau blimbing basi (nama ilmiah: averrhoa carambola) digunakan daunnya untuk mengobati sesak nafas atau asma;

35. Kasimbukan atau Kasimbukan (nama ilmiah: paederia foetida L) digunakan daun dan getahnya untuk mengobati bitnik-bintik pada kulit bayi;

36. Taru Dangolo atau pohon gandolo, gondola (nama ilmiah: bassella rubra L) digunakan daunnya untuk jamu dalam mengobati muntah-muntah dan diare;

37. Taru Pepe atau Pohon Kpepe (nama ilmiah: sarcostemma esculentum) digunakan daunnya untuk mengobati muntah-muntah dan muntaber;

38. Paya atau Pohon Pare (nama ilmiah: momurdica charantia) digunakan akarnya, daunnya utnuk mengobati orang pingsan;

39. Tuwung atau Terong, jeruk sitrun (nama ilmiah: citrus aurantifolia) digunakan daunnya untuk mengobati sakit pegal-pegal;

40. Uyah-uyahan atau uyah-uyah (nama ilmiah: ficus quercifolia) digunakan daunnya untuk mengobati korengan pada kulit;

41. Taru Manggi atau semanggi (nama ilmiah: marselia crenata) digunakan daunnya untuk mengobati korengan pada kulit;

42. Parcarsona atau pancarsona (nama ilmiah: tinospora coriaceae) digunakan serat kulit kayunya untuk mengobati mual-mual;

43. Juwet atau pohon juwet, sekui,duwet (nama ilmiah: eugenic cumini druse) digunakan buahnya untuk mengobati sakit kelamin (sipilis);

44. Nyuh gading atau kelapa gading (nama ilmiah: cocos nucifera L) digunakan serat kulit, airnya untuk mengobati sakit panas, sakit gila dan leteh;

45. Taru Cremen atau Pohon Ceremai (nama ilmiah: phyllanthus acidus) digunakan buahnya untuk mengobati luka pada jari-jari;

46. Manas atau Nanas (nama ilmiah: annanas $s p$ ) digunakan buahnya untuk mengobati kencing nanah;

47. Wit Sempol atau Iwit Sempol (nama ilmiah: hedychium ceronarium) digunakan daunnya untuk mengobati sakit panas;

48. Myanacemeng atau miana cemeng (nama ilmiah: coleus scutellarrioides) digunakan kulit kayunya untuk mengobati sakit panas;

49. Taru ancak atau ancak (nama ilmiah: ficus religiosa) digunakan getahnya untuk mengobari lelah dan pegal-pegal;

50. Taru wani atau kemang (nama ilmiah: mangifera caesia jack) digunakan daun, dan getahnya untuk mengobati pendengaran pada telinga (bernanah);

51. Taru Bang atau pohon bang digunakan daunnya untuk mengobati penyakit kulit;

52. Kakara manis atau kacang kara (nama ilmiah: phaseolus oleracea L) digunakan kulit buahnya untuk mengobati sariawan;

53. Poh gedang atau mangga kestri (nama ilmiah: mangifera indica) digunakan buahnya untuk menghilangkan sakit saat keguguran dan aborsi;

54. Katimun Gantung atau ketimun gantung (nama ilmiah: cucumis sativus) digunakan akar, daunnya untuk menghilangkan sakit saat keguguran atau aborsi;

71 | SANJIWANI: Jurnal Filsafat Vol. 12 No. 1, Maret 2021 
55. Keladi atau talas (nama ilmiah: colocasia plumbea) digunakan daunnya untuk mengobati sakit panas dan susah tidur;

56. Liligundi atau legundi (nama ilmiah: vitex trifolia L) digunakan untuk mengobati sakit panas.

57. Base atau Sirih (nama ilmiah: piper betle L) digunakan daunnya untuk mengobati sakit pada badan seperti pegal;

58. Damuh-damuh atau damuh-damuh (nama ilmiah: merrenia emarginata HALL) digunakan kulit kayunya untuk mengobati sakit perut setelah melahirkan;

59. Taru buwu atau buwu digunakan daunnya untuk mengobati penyakit rematik;

60. Taru Terong atau terung (nama ilmiah: citrus aurantifolia) digunakan daunnya untuk mengobati bintil-bintil pada kulit atau saraf;

61. Taru majagawu atau pohon gaharu (nama ilmiah: aquilaria sp) digunakan kulit kayu, getah, akar dan daunnya untuk mengobati mual-mual;

62. Taru limo atau jeruk limo (nama ilmiah: citrus amblicarpa) digunakan daun dan akarnya untuk mengobati semutan atau rematik;

63. Taru kecubung atau kecubung (nama ilmiah: datura metel L) digunakan bunga, getah, daun dan akarnya untuk mengobati guna-guna;

64. Sekapa atau gadung (nama ilmiah: Diosscorea hispida L) digunakan buah, akar, daunnya untuk mengobati sakit bisul;

65. Taru pangi atau keluak (nama ilmiah: pangium edule) digunakan pucuk daunnya untuk mengobati mimisan pada hidung;

66. Ikuh lutung putih atau ikut lutung putih (nama ilmiah: acalipha hispida) digunakan daunnya untuk mengobati mata yang tumbuh daging;

67. Legundi kebo atau legundi (nama ilmiah vitex trifolia L) digunakan daunnya ntuk mengobati sakit lumpuh;

68. Taru sembung atau sembung (nama ilmiah: blumea balsanifera dc) digunakan isi buahnya untuk mengobati obat panas dalam pada perut;

69. Taru tingkih atau kemiri (nama ilmiah: aleurites molluccana willd) digunakan kerikan buahnya untuk memberikan tenaga kepada bayi sebelum kepus pusar;

70. Taru Api atau kayu api digunakan getahnya untuk mengobati orang gila;

71. Taru panyisih atau peyisih (nama ilmiah: phyllanthuis buxifolius) digunakan akar, getah dan daunnya untuk mengobati hidung orang kena bebai (magic)

72. Taru Pahang atau Pahang (nama ilmiah: acasia robusta wild) digunakan bunganya untuk mengobati sakit bengong atau memegeng;

73. Taru mawa atau kayu mawa digunakan kulit kayu, daun dan getahnya untuk mengobati sakit tersedu-sedu;

74. Taru cenana atau kayu cendana (nama ilmiah: santalium almbum $L$ ) digunakan getah, akar dan kulit kayunya untuk mengobati cacar pada bayi, dan sariawan;

75. Taru sembung tulang atau kayu patah tulang (nama ilmiah: euphorbia turivalling $L$ ) digunakan akar, daun, dan serat kayunya untuk mengobati levera dan kusta;

76. Taru Jali atau jail (nama ilmiah: coix lacryma-jobi L) digunakan pucuk daun, akar dan getahnya untuk mengobati buta atau tetes mata;

72 | SANJIWANI: Jurnal Filsafat Vol. 12 No. 1, Maret 2021 
77. Taru munggi atau marunggi digunakan daun dan akarnya untuk mengobati mata buta;

78. Taru Kroya atau pohon kroya (nama ilmiah: ficus infectoria) digunakan daun dan akarnya untuk mengobati kejang-kejang;

79. Taru uwut-uwut atau kayu uwut-uwut (nama ilmiah: aleurite moluccana) digunakan akar dan daunnya untuk mengobati patah tulang;

80. Taru tingulun atau kayu tingulun (nama ilmiah: protium javanicum) digunakan pucuk daun dan akarnya untuk mengobati diare;

81. Taru puring atau pohon puring digunakan buahnya untuk mengobati tuli pada telinga;

82. Taru jepun atau pohon kamboja digunakan serat kayunya untuk mengobati sakit pinggang

83. Taru mas atau pohon mas digunakan getah, akar dan serat kayunya untuk mengobati sembelit;

84. Taru tehep atau bendo (nama ilmiah: artacarpus) digunakan daun, akar dan serat kayunya digunakan untuk mengobati sakit pada lidah;

85. Taru paspasan atau pohon paspasan digunakan akar, daun, dan serat kayunya untuk mengobati sakit panas;

86. Taru piling atau saga (nama ilmiah: abrus precatoris $L$ ) digunakan daunnya untuk mengobati rasa kehausan tiada hilang-hilang;

87. Taru bunut bulu atau bunut bulu (nama ilmiah: ficus annulate) digunakan kulit kayu dan daunnya untuk mengobati sesak nafas;

88. Taru kaleyan atau kalian (nama ilmiah: bleghia sp) digunakan daun, getah, kulit kayunya untuk mengobati diare;

89. Crangcang kawat atau pohon asparagus (nama ilmiah: asparagus sp) digunakan akarnya untuk mengobati luka;

90. Taru teter atau pohon teter digunakan getah, akar, dan daunnya untuk mengobati sakit gigi;

91. Taru poh heni atau manga heni (nama ilmiah: mangifera $s p$ ) digunakan untuk mengobati lemah jantung dan diet;

92. Slikaya atau Silik digunakan serat kayunya untuk mengobati tidak enak badan;

93. Taru bawang-bawang atau pohon bawang (nama ilmiah: premna obtusifolia) digunakan daunnya untuk mengobati sembelit atau disentri;

94. Taru pucuk atau kembang sepati (nama ilmiah hibiscus rosasinensis) digunakan serat kayunya untuk mengobati proses kelahiran dengan memperlancar;

95. Taru kepahai atau pohon kepah (nama ilmiah: stercukea foetida L) digunakan daunnya untuk menghilangkan racun ular;

96. Taru suri atau pohon suri digunakan serat kayunya untuk mengobati sakit nelu;

97. Taru basa-basa atau pohon basa-basa (nama ilmiah: clausena sp) digunakan semuanya untuk mengobati sakit mencret yang tidak kunjung berhenti;

98. Taru uduh atau pohon uduh (nama ilmiah: pinanga coronata) digunakan daun, akar dan getar untuk mengobati lemah syahwat;

99. Taru klampuak atau pohon klampwak digunakan daun, akar, serat kayu dan getahnya untuk menggemukan badan atau mengobati orang kurus;

73 | SANJIWANI: Jurnal Filsafat Vol. 12 No. 1, Maret 2021 
100. Taru gedang atau papaya (nama ilmiah: carica papaya) digunakan getahnya untuk mengobati orang yang terkena gigitan lipan atau kelabang;

101. Taru pancarsona atau pancarsona (nama ilmiah: tinospora coriaceae) digunakan daunnya untuk mengobati penyakit jahat (black magic);

102. Taru galing-galing atau galing-galing (nama ilmiah: cayratia trifolia) digunakan serat kayunya untuk mengobati sakit perut atau desentri;

103. Taru dagadagse atau kolbanda (nama ilmiah: pisonia alba span) digunakan serat kayunya untuk mengobati pegal-pegal pada kaki;

104. Taru lambon kutuh atau ketela pohon putih (nama ilmiah: manihot uttilisima) digunakan akar dan akarnya untuk mengobati sakit badan;

105. Taru krasi atau pohon lantana (nama ilmiah: lantana camara) digunakan daunnya untuk mengobati mual-mual dan mabuk.

106. Taru kenari atau pohon kenari (nama ilmiah: canarium vulgare) digunakan pucuk daunnya untuk mengobati sakit kepala;

107. Taru bawang-bawang brahma (nama ilmiah: allium cepa) digunakan getahnya untuk mengobati mimisan;

108. Taru keladi gowak atau pohon talas hitam (nama ilmiah: alocasia plumbea) digunakan getahnya untuk mengobati gatal-gatal pada kulit;

109. Taru manggis atau pohon manggis (nama ilmiah: garcinia mangostana I) digunakan getahnya untuk mengobati krambit naga atau tilas naga;

110. Taru cempaka kuning atau pohon cempaka kuning (nama ilmiah: millingtonia hortensis) digunakan sisik kayunya untuk mengobati orang yang tidak bisa tidur;

111. Taru Kalimoba atau kayu ombo (nama ilmiah: ficus binendiskii) digunakan getah, dan serat kayunya untuk mengobati sakit gigi;

112. Taru Jempiring atau kaca piring (nama ilmiah: gardenia florida L) digunakan daunnya untuk mengobati anak sakit tidak mau makan;

113. Taru palitsedangan atau palit sedang (nama ilmiah: thevea peruviana K.Schum) digunakan getah, dan daunnya untuk mengobati sakit mata;

114. Gadung kasturi atau gadung kasturi (nama ilmiah: dioscorea pentaphylla) digunakan getah, dan akarnya untuk mengobati sakit asma dan batuk;

115. Taru awar-awar atau awar-awar (nama ilmiah: ficus septica) digunakan daunnya untuk mengobati sakit muntaber;

116. Bun mica atau tanaman merambat merica (nama ilmiah: piper ningrum) digunakan daunnya untuk mengobati sakit kepala;

117. Gamongan atau lempuyang (nama ilmiah: zingibera zerumbet) digunakan umbinya untuk mengobati keseleo pada tangan;

118. Kliki atau jarak kepyar (nama ilmiah: jatropha curcus L) digunakan getahnya untuk mengobati sakit bengkak pada tangan;

119. Taru manis atau katu (nama ilmiah: sauropus androginus) digunakan akar dan daunnya untuk mengobati suara serak;

120. Manas bang atau pohon manas bang digunakan buah nya untuk mengobati hidung dengan diteteskan dan untuk sakit tulang

121. Taru kadongdong atau kedongdong (nama ilmiah: spondiac dulcis) digunakan serat kayunya untuk mengobati luka berung pada kulit;

74 | SANJIWANI: Jurnal Filsafat Vol. 12 No. 1, Maret 2021 
122. Taru Musi atau musi digunakan daunnya untuk mengobati sakit kulit kemerah-merahan;

123. Taru ingan-ingan atau ingan-ingan (nama ilmiah: flemingia congesta roxb) digunakan daunnya untuk mengobati anak kecil yang belum bisa berjalan;

124. Taru tigaron atau tigaron (nama ilmiah: crataeca nurvala buch ham) digunakan daunnya untuk mengobati orang gila atau sinting pada matanya;

125. Taru pengeng-pengeng (nama ilmiah: pedilanthus tithymaloides) digunakan daunnya untuk mengobati sakit kepala yang disertai dengan pusing;

126. Taru tilap atau pohon tilap digunakan daunnya untuk loloh dalam mengobati sakit lever;

127. Taru teter atau pohon teter digunakan serat kayunya untuk mengobati sakit perut semacam keram;

128. Taru bowok atau bowok digunakan serat kayunya untuk mengobati orang sakit hati;

129. Taru merak atau merak digunakan bunganya untuk mengobati anak kecil yang sering menangis malam hari;

130. Teleng atau teleng (nama ilmiah: Clitoria ternatea L) digunakan daunnya untuk mengobati kejang-kejang;

131. Taru tamplas atau amplas (nama ilmiah: ficus ampelas burm F) Digunakan getahnya untuk mengobati bibir pecah-pecah (belatukan);

132. Kasa-kasa atau kapulaga (nama ilmiah: anomum maximum roxb) digunakan akarnya, dibuatkan jamu untuk mengobati dan memperlancar proses persalinan;

133. Taru udak atau kayu udak digunakan serat kayunya untuk mengobati rasa kesakitan saat hamil;

134. Kamurugan atau kamurugan (nama ilmiah: gymnospetalum sp) digunakan daunnya untuk mengobati sakit kepala;

135. Taru Kuanta atau atau kwanta digunakan buahnya untuk mengobati sesat nafas;

136. Bun paperon atau ki kuning (nama ilmiah: arccangelisia) digunakan daunnya untuk mengobati belahan sakit pada kepala;

137. Jarak atau jarak pagar (nama ilmiah: ricinus communis L) digunakan serat kayunya untuk mengobati sakit tuli pada telinga;

138. Blego atau bligo (nama ilmiah: berincasa hispida $\operatorname{cogn}$ ) digunakan buahnya untuk mengobati anak menangis tanpa sebabnya dan bermurung diri;

139.Taru sikep atau pohon sikep digunakan daunnya untuk mengobati sakit kejitkejit atau saraf;

140. Kangkang yuyu atau kangkang yuyu (nama ilmiah: cyclea barbata) digunakan akarnya untuk mengobati sakit gangguan pernafasan, serta leher;

141. Kesawi bang atau kesawi merah digunakan daunnya untuk mengobati sakit leher;

142. Paku jukut atau pakis sayur (nama ilmiah: athyrium esculentum) digunakan daunnya untuk mengobati orang yang tidak ada nafsu makan;

143. Taru pulir atau pohon pulir digunakan akarnya untuk mengobati penyakit jantung berdebar-debar;

75 | SANJIWANI: Jurnal Filsafat Vol. 12 No. 1, Maret 2021 
144. Kapas atau kapas (nama ilmiah: gossypium barbecius) digunakan akar dan daunnya untuk mengobati sakit pada saat lepas puser pada bayi dan lemah jantung;

145. Kepasilan juuk atau benalu jeruk (nama ilmiah: viscum articulatum) digunakan daunnya untuk mengobati anak muntah-muntah;

146.Samblung atau samlung (nama ilmiah: epipremnum pinatum ENGL) digunakan akarnya untuk mengobati sakit epilepsy atau ayan;

146.Taru Belimbing basi atau belimbing basi (nama ilmiah: averrhoa bilimbi) digunakan buahnya untuk mengobati sakit asma dan batuk;

147.Taru pala atau pohon pala digunakan serat kayunya untuk mengobati sakit dalam;

148.Taru kutuh atau kapuk randu (nama ilmiah: ceiba petandra) digunakan embungnya untuk mengobati sakit sariawan pada bayi yang sulit makan;

149.Taru kelasih atau telasih (nama ilmiah: ocimum bacilicum l) digunakan daunnya untuk mengobati sakit disentri;

150. Taru kenari atau kenari (nama ilmiah: canarium vulgare) digunakan serat kayunya untuk mengobati sakit kepala;

161. Taru kenarak atau rerak (nama ilmiah: sapindus rarak Dc) digunakan serat kayunya untuk mengobati mual-mual;

162. Taru poh amplem atau mangga amplem (nama ilmiah: magifera $s p$ ) digunakan serat kayunya untuk mengobati sakit menusuk-nusuk pada perut bagian samping;

163. Tiing Ampel Gading atau bambu ampel gading (nama ilmiah: bambosavulgaris) digunakan serat kayunya untuk mengobati wajah karena sakit sembab atau semug;

164. Taru tinga-tinga atau tinga-tinga digunakan akarnya untuk mengobati haus tiada henti dan sebabnya;

165. Taru Pulasari atau pulasari digunakan daunnya untuk mengobati sakit lelengedan;

166. Taru Kasahe atau kasahe digunakan daunnya untuk mengobati sakit migran dan sakit kepala sebelah;

167.Taru padi-padi atau padi-padi digunakan daun umbinya untuk mengobati memar, bengkak, mata merah pada wajah dan tidak ada nafsu makan;

168. Tiih atau suwek duri (nama ilmiah: amorphopalus $s p$ ) digunakan umbinya untuk mengobati telapak kaki yang sakit (entelan);

169. Taru Pasparan atau paspara digunakan akar dan daunnya untuk mengobati sakit migren;

170. Taru awar-awar Brahma atau awar-awar merah (nama ilmiah: ficus septica) digunakan daun dan batangnya untuk mengobati orang yang tergigit ular hitam putih;

171. Ketimun $u k u$ atau mentimun rambat (nama ilmiah: cucumis sativus) digunakan daunnya yang berwarna kuning untuk mengobati sakit perut mulas-mulas pada wanita hamil tiga bulan;

172.Tebu malem atau tebu hitam (nama ilmiah: saccharum officinarum) digunakan satu tumbuhannya untuk mengobati sakit buh;

76 | SANJIWANI: Jurnal Filsafat Vol. 12 No. 1, Maret 2021 
173.Taru tanjung atau tanjung digunakan serat kayunya untuk mengobati sakit buh;

174.Taru kembang kuning digunakan pucuk daunnya untuk mengobati sakit otot atau bahu kaku;

175.Taru Raso atau pohon raso digunakan daunnya untuk mengobati anak kecil yang menangis tiada henti-hentinya;

176.Taru tapis-tapis atau tapis-tapis digunakan daunnya untuk mengobati bengkak pada paha;

177.Taru paku lelipi atau paku (nama ilmiah: crassula sp) digunakan daunnya untuk mengobati sengatan kalajengking;

178. Taru Silikaya jawa atau silikiya jawa digunakan daunnya untuk mengobati perut kembung;

179. Kasegseg atau kasegsegan (nama ilmiah: purtulaca oleracea L) digunakan daunnya untuk mengobati sakit perut melilit.

\subsection{Lontar Taru Pramana dalam Kontruksi Filsafat Ilmu}

Filsafat ilmu merupakan bagian filsafat pengetahuan atau epistemologi. Filsafat pengetahuan (epistimologi) yang disebut pula dengan The Theory of Knowledge. Filsafat menelaah objek kajiannya atas dasar tiga sudut pandang yaitu Ontologi, Epistemologi dan Aksiologi, yang biasa dikenal dengan istilah tiangtiang penyangga eksistensi ilmu (Siswomihardjo, 1985). Landasan ontologi dalam pengembangan ilmu merupakan titik penelaahan ilmu pengetahuan didasarkan atas sikap dan pendirian filosofis yang dimiliki oleh seseorang. Landasan epistemologis merupakan pengembangan ilmu dalam titik penelaahan ilmu pengetahuan didasarkan atas cara dan prosedur dalam memperoleh kebenaran, serta landasan aksiologi merupakan pengembangan ilmu dan sikap etis yang harus dikembangkan, terutama dalam kaitannya dengan nilai-nilai yang dinyakini kebenarannya.

Jika dipahami sesungguhnya ruang lingkup filsafat ilmu meliputi objek material (ilmu pengetahuan dan metode secara sistematis) dan objek formal (hakikat atau esensi dari ilmu pengetahuan) sehingga aktivitas ilmiah senantiasa dikaitkan dengan kepercayaan, ideologi yang dianut oleh masyarakat atau bangsa tempat ilmu itu dikembangkan. Sesungguhnya isi teks lontar Taru Pramana terkontruksi dalam filsafat ilmu. Lontar tersebut dengan jelas di sangga oleh tiga hal mendasar dalam filsafat yaitu ontologis, epistemologi dan aksiologinya. Ketiga hal tersebut berkaitan dan membangun ilmu pengobatan herbal tradisional dengan menggunakan tumbuh-tumbuhan sebagai fokus utamanya. Tumbuh-tumbuhan itu dalam teks lontar Taru Pramana diceritakan dapat berbicara dan menjelaskan khaziat mereka untuk pengobatan. Secara ontologis, epistemologi dan aksiologi tersurat secara mendalam pada salah satu contoh kasus tumbuhan dalam lontar Taru Pramana, sebagai berikut.

Titiang i taru bingin maka pasilihan Ida Sang Hyang Surya Candra. Inggih sekar titiang tis, daun titiang panes, angurip wong lara pamalinan. Kantin titiang i mesui. Ika anggen sembar. Malih bangsing titiang tis angurip wong lara, makanti ring bawang adas. Babakan titiang panes, gempong titiang dumalada. I Taru bingin mapamit. "saya bernama pohon beringin sebagai penjelmaan matahari dan bulan. Bunga saya 
sejuk, daun saya panas mengobati manusia terkena sakit pamali (sakit semacam kram, menusuk-nusuk pada bagian tubuh). Dicampur dengan mesui (rempahrempah pd serat kayu). Itu disemburkan pada bagian tubuh yang sakit. Selanjutnya akar bingin saya terasa sejuk digunakan untuk menyembuhkan orang sakit, dicampurkan dengan bawang dan adas. Kulit saya terasa panas, pucuk daun saya terasa hambar (tanpa rasa). Saya pohon Bringin memohon pamit".

Berdasarkan kutipan teks lontar Taru Pramana tersebut dapat dipahami bahwa aspek ontologisnya membahas tentang hakikat yang ada pada pohon bringin Titiang $i$ taru bingin maka pasilihan Ida Sang Hyang Surya Candra "saya bernama pohon beringin sebagai penjelmaan matahari dan bulan", menandakan ultimate reality dalam aspek ontologis baik yang berbentuk kongkret dan rohani. Aspek epistemologi penggunaan pohon bringin "Inggih sekar titiang tis, daun titiang panes, angurip wong lara pamalinan. Kantin titiang i mesui. Ika anggen sembar. Malih bangsing titiang tis angurip wong lara, makanti ring bawang adas. Babakan titiang panes, gempong titiang dumalada "Bunga saya sejuk, daun saya panas mengobati manusia terkena sakit pamali (sakit semacam kram, menusuk-nusuk pada bagian tubuh, biasanya pada perut). Dicampur dengan mesui (serat kayu). Itu diolah dan disemburkan pada bagian tubuh yang sakit. Selanjutnya akar bingin saya terasa sejuk digunakan untuk menyembuhkan orang sakit, dicampurkan dengan bawang dan adas. Kulit saya terasa panas, pucuk daun saya terasa hambar (tanpa rasa)" berdasarkan tersebut jelas epistemologi dari penggunaan pohon Bringin sebagai obat. Melalui titik penelaahan ilmu pengetahuan pengobatan tradisional berbasiskan herbal, maka epistemologi dalam lontar Taru Pramana didasarkan atas cara dan prosedur memperoleh kebenaran penggunaan pohon Bringin, sebagai salah satu contohnya. Sedangkan aksiologi dari penggunaan pohon Bringin adalah angurip wong lara pamalinan "menyembuhkan orang yang terkena penyakit pamalin". Inilah aksiologi dari salah satu contoh tumbuhan pada lontar Taru Pramana dengan mengedepankan nilai yang berkenaan dengan etika perbuatan manusia dalam menjaga lingkungan dan ekosistem, jika ditinjau dari suatu kondisi yang melibatkan norma-norma yang dimiliki oleh manusia terhadap lingkungan dan fenomena di sekelilingnya, serta ini merupakan kebermanfaatan lontar Taru Pramana dalam kontruksi filsafat ilmu bagi pembaca untuk memahami penggunaan tumbuhan sebagai bahan obat herbal.

\section{PENUTUP}

Lontar Taru Pramana adalah lontar yang berisi tentang khaziat tumbuhan dalam pengobatan tradisional Bali. Melalui isi teks lontar Taru Pramana, harus wajib diberikan perhatian khusus dengan mengkontruksikan pemahaman filsafat ilmu kedalamnya. Oleh karena filsafat ilmu berusaha menjelaskan masalah-masalah dimulai dari suatu konsep dan pernyataan, sehingga dapat dinyatakan sebagai ilmiah. Semua pengetahuan tersebut merupakan wujud konkrit dari pengalaman manusia yang dituangkan dan terdokumentasikan dalam khazanah teks lontar terutamanya lontar Taru Pramana. Menandakan bahwa pengalaman para leluhur terdahulu dalam mengobati penyakit telah 
memahami ekosistem tumbuh-tumbuhan, yang berguna dalam proses penyembuhan dan pengobatan. Sangat jelas diuraikan penggunaan tumbuhtumbuhan yang dapat digunakan sebagai obat pada lontar Taru Pramana, dengan disangga oleh tiga hal mendasar dalam filsafat yaitu ontologis, epistemologi dan aksiologinya. Ketiga hal tersebut berkaitan dalam membangun ilmu pengobatan herbal tradisional dengan menggunakan tumbuh-tumbuhan sebagai fokus utamanya.

\section{DAFTAR PUSTAKA}

Adib, Mohammad. 2010. Filsafat Ilmu (Ontologi, Epistemologi, Aksiologi dan Logika Ilmu Pengetahuan). Yogyakarta: Pustaka Pelajar.

Arsana, I Nyoman. 2019. Keragaman Tanaman Obat dalam Lontar “Taru Pramana" dan Pemanfaatannya untuk Pengobatan Tradisional Bali dalam Jurnal Kajian Bali. Denpasar: Pusat Kajian Bali dan Pusat Unggulan Pariwisata Universitas Udayana.

Jumadiah, Sri. 2009. Usada Taru Pramana. Denpasar: Yayasan Dharma Pura.

Mustansyir, Rizal dan Misnal Munir.2010. Filsafat Ilmu. Yogyakarta: Pustaka Pelajar.

Siswomihardjo. 1985. Ilmu Filsafat dan Aktualitasnya dalam Pembangunan Nasional. Pidato Pengukuhan Jabatan Guru Besar Pada Fakultas Filsafat Universitas Gajah Mada Yogyakarta

Sukersa, I Wayan. 1996. Usada Taru Pramana: Suatu Kajian Filologis. Tesis Magister Humaniora. Bandung: Progam Pascasarjana Universitas Padjajaran.

Sukersa, I Wayan. 2017. Usada Taru Pramana: Sebuah Wahana Pelestarian Flora Bahan Obat Tradisional Bali dalam Buku Prabhajnana Kajian Pustaka Lontar Universitas Udayana (hal 1-26). Denpasar: Swasta Anulus.

Utami, Tri Niswati \& Reni Agustina Harahap. 2019. Sosioantropologi Kesehatan Integrasi Budaya dan Kesehatan. Jakarta: Prenadamedia Group. 